Journal of Teacher Education for Sustainability, vol. 18, no. 2, pp. 5-20, 2016

\title{
Key Stakeholders' Attitudes towards Teacher Education Programs in TEFL: A Case Study of Farhangian University in Iran
}

\author{
Javad Gholami and Isa Qurbanzada \\ Urmia University, Urmia, Iran
}

\begin{abstract}
Recently, teacher training courses have attracted the researchers' special attention, while teacher education programs have not received as much attention. The present study investigated the attitudes key stakeholders in a teacher education program (i.e., student teachers, in-service teachers, and teacher educators) hold toward the appropriateness of TEFL teacher education programs at an Iranian teacher education university and their relevance to and sustainable impact in the real teaching context. To this end, 62 pre-service teachers, 48 in-service teachers, and 28 teacher educators filled out the Foreign Language Teacher Education Program Evaluation questionnaire adapted from Peacock (2009). The results of ANOVA tests indicated that the pre-service teachers and teacher educators found courses with literary strands less relevant to English language teaching and believed that those courses should be modified or replaced by teaching more knowledge-building or knowledge-applying subjects. In addition, the in-service teachers harboured a negative perspective towards the courses which were not practical in the real classroom setting and considered them less empowering. All three groups found teaching-related courses, such as teaching methodology, of more sustainable nature and useful in the real teaching context. Besides, the participants believed that it is essential for the universities to incorporate several practical courses including practicum and classroom observations within the curriculum. This study suggests that accommodating key stakeholders' preferences in a teacher education programs could lead to crafting more accountable and empowering teacher education programs.
\end{abstract}

Keywords: In-service teachers, Pre-service teachers, Teacher education, Teacher educators, Teacher education program evaluation

\section{Introduction}

Nowadays, English has become the international language throughout world and is widely used in daily communication and business. This has made the need for exploring the field of English language instruction and learning even more crucial within the general educational system whereby teachers are being educated and trained. Since teachers have the most highlighted contribution in students' learning as well as the 
effectiveness of the educational systems, most studies in English Language Teaching (ELT) have centered on teachers' professional development and education both of which play important roles in teachers' effective performance and in learners' success in the classroom. As Seyoum (2016) states, continuing professional development is directly related to high quality teaching and learning. Although professional development programs are an effective way to enhance teachers' performance in the classroom and improve their practice through an ongoing process, the role of teacher education programs should not be overlooked. In fact, those programs act as the building blocks of teachers' knowledge in respect to their understanding of teaching and learning theories. As a result, the need is felt to develop an appropriate and structured evaluative system within pre-service teacher education programs which may lead to a more improved and effective educational program.

Peacock (2009) argues that teacher-training programs must involve internal evaluation systems within their programs. The main reason for employing those internal evaluation systems is to increase the accountability of the program to the stakeholders (White, 1998; Lynch, 2003). As Peacock (2009) states, the evaluation of pre-service teacher education programs would result in the professionalization of the ELT field and make a useful contribution to the robustness of the theoretical backgrounds. Rea-Dickins and Germaine (1998) contended that systematic evaluation should be placed at the very heart of a program. In addition, Al Barwani, Al-Mekhlafi, and Nagaratnam (2013) argue that the validity of the curricula, policies, methods, and even principles in Middle Eastern countries are being questioned, and, hence, they have turned to educational reform and school improvement as the most practical choice. It goes without saying that more judicious reforms can be enacted through evaluation of the programs.

Evaluation of teacher education programs can also lead to more sustainable practices and outcomes in these programs. As Gholami, Sarkhosh, and Abdi (2016) put, sustainable behavior of teachers in the classroom is considered as one of the characteristics of efficient teachers. According to Besong and Holland (2015), sustainability is something that goes on continuously and for a long period of time. Redman (2013) points out that sustainability in education leads to change in behavior. However, how to develop a sustainable educational system is of utmost importance. The main objective of this study was to investigate the three key stakeholders' (i.e. pre-service teachers, in-service teachers, and teacher educators) opinions about the courses presented at Farhangian University, a leading teacher education university in Iran. Definitely, the opinions of these three stakeholders could be of instrumental value in promoting sustainable teacher education in the short run and student education in the long run.

According to Day (1991), the concept of Foreign Language Teacher Education and its developments have been under-researched areas in the recent years. Likewise, Weir and Roberts (1994) confirmed that the studies conducted on the evaluation of teacher education programs have been limited in number indeed.

As Widdowson (1990) states, novice teachers need to be confident when faced with difficult, new, and, even sometimes, threatening situations in class. To have this confidence, he states that they need to rely on a series of established and reliable techniques, which assist them in dealing with such adversity. It is quite clear that teachers get familiar with such techniques in their pre-service training programs. Teacher training programs may fail to develop such confidence in teachers. Therefore, evaluation of these programs is beneficial and necessary in order to prepare more confident and efficient 
teachers. Indeed, the importance of teacher education program evaluation has been noted by some experts in the field such as Bretta and Davies (1985), Yang (2009), and Sullivan (2006) as there have been some complaints from graduates, school authorities, and policy makers on the appropriateness of these programs (Barone, Berliner, Blanchard, Casanova, \& McGowan, 1996; Sandlin, Young, \& Karge, 1992).

Pre-service teacher education program is defined as a course which prepares the teachers prior to the real teaching experience (Richards \& Schmidt, 1985). These courses aim at preparing the student teachers for the real practice of teaching by making them familiar with the teaching methodology, techniques, as well as practices. Pre-service teacher training courses should encompass broad general themes related to language learning and teaching and different kinds of activities to make the student teachers more knowledgeable on those grounds. As Lucas, Villegas, and Freedson-Gonzalez (2008) state, "pre-service teacher education programs can engage prospective teachers in various types of activities that will prepare them to learn about ELLs in their future classes" (p. 367).

Some studies have been carried out on evaluation of teacher preparation courses. A study by Al-Gaeed (1983) in Saudi Arabia aimed at pinpointing the weak and strong points of an English teacher education program by asking the student teachers and the graduates' opinions about the course. The results revealed that both groups hold positive attitudes towards the linguistics, methodology, and teaching practice courses as well as the knowledge and quality of the professors. However, they argued that the program should include some courses to improve their oral abilities and provide them with more communicative opportunities. They also found the literature-related courses irrelevant to their preparation.

In another study, Cosgun-Ogeyik (2009) evaluated the courses presented in the curriculum of an English teacher education program in Turkish universities. The results indicated a general positive evaluation of the course by the trainees courses provided in the program are consistent with their needs and expectations regarding outlining the goals of teaching profession, social objectives, and benefits obtained from the program. On the other hand, they suggested that the program needed to include some courses that were more culture specific.

In an evaluation study, Erozan (2005) evaluated the language improvement courses in the undergraduate curriculum of the Department of ELT at Eastern Mediterranean University. The findings indicated that both instructors and students were satisfied with the courses in general; however, they recommended that some changes be made in the courses in order to make them more effective and in line with the pre-service teachers' needs and expectations and the course should contain more practice and production, the use of more authentic materials from diverse sources, and the continuity and coherence between the courses be strengthened.

Seferoglu (2006) explored the attitudes of pre-service teachers towards practice and methodology components of pre-service English teacher training program in Turkey through a qualitative study. The results indicated that the senior student-teachers believed that the courses presented during the program were not really useful in practice in real classrooms. They also stated that the micro-teaching and practice teaching opportunities during the course were not sufficient.

This brief sketch of the literature demonstrates that although professional development courses have been the focus of most of the previous studies, the evaluation of pre- 
service education programs has not been researched much so far. Moreover, no attempts have been made to evaluate the pre-service teacher training courses in terms of the perspectives of these three key stakeholders, namely teacher trainers, pre-service teachers, and in-service teachers at the same time and in on context. Hence, the present study aims to explore how these stakeholders evaluate a pre-service teacher education course as well as to examine their attitudes toward the relevance of the courses presented in the program to their future application in the real teaching contexts. We believe that more accountable results could be gained if we investigate the opinions of other key stakeholders. In addition, to our best knowledge, such studies are generally missing in the Iranian context.

\section{The Methodology of the Research}

\section{Participants}

Three groups of participants took part in the present study. The first group consisted of 62 pre-service teachers who were senior BA students in TEFL at three Farhangian Universities (FUs) and familiar enough with all of the courses provided by FU. The preservice group included 35 female and 27 male students with a mean age of twenty-four. The second group constituted 48 in-service EFL teachers who were TEFL graduates (Mean age 29) and had at least four years of teaching experience in public schools. Finally, the third group comprised 28 teacher educators (18 male, 10 female, mean age: 56) who were teaching courses related to TEFL at four Iranian state universities or teacher education universities which offered BA programs in TEFL.

\section{Procedure}

In order to explore the attitudes of the participants towards the relevance of the BA courses to their use in the real teaching context, an adapted version of Peacock's (2009) Foreign Language Teacher Education Program Evaluation questionnaire was used. This questionnaire was adapted in order to comply with the courses presented at FUs in Iran.

The questionnaire consisted of two parts. In the first part, the participants were required to evaluate the courses presented in each semester based on Fridman Rank Order Scale ranging from 1 to 10 for the responses. The score of 1 indicated the least amount of relevance, and the score of 10 indicated the highest amount of relevance of the courses to their use in the teaching context. In the second section, the participants provided their comments with regards to the maintenance and omission of the courses within the program.

In case the participants rated for the necessity of the courses, they were free to write their suggestions for further improvements in the parts allotted for this purpose at the end of the questionnaire. On the other hand, if the participants believed that the course should be excluded from the program, they were given the chance to specify a tentative replacement for that course. They could write the name of the course in a section in front of the course they thought as irrelevant as well as in a separate section at the end of the questionnaire (see Appendix for more details on the questionnaire). 
Copies of the questionnaire were administered among the participants in order to discern their attitudes toward the relevance of the BA in TEFL to their sustainable use in the real teaching practice. The questionnaires were distributed during the 2015-2016 academic year. The reliability of the questionnaire was checked for the three groups. The Cronbach alpha coefficients of the questionnaire for teacher educators, pre-service teachers, and in-service teachers were found to be $0.91,0.87$, and 0.88 , respectively. The validity of the questionnaire was also confirmed by two ELT experts, each holding a PhD in TEFL. The questionnaires were personally administered to the participants by the second researcher, and the study details were explained to them. Instructions on how to fill the questionnaire were also provided to the participants. The questionnaires were delivered to the student teachers at the end of the fall semester in 2015 so that they could express their opinions about the courses with more insightful views on the courses.

To analyse the data, a series of One-way between groups ANOVAs were run in order to see if a significant difference existed among the groups with regard to their attitudes toward the courses presented in the BA program in TEFL at FU. The ANOVAs were run for each lesson in separation. The alpha level in all the analyses was set at $p<$ .05. All the statistical analyses were carried out using Statistical Package for the Social Sciences (SPSS), version 18.

\section{Results}

The present study attempted to examine the perspectives of three groups of key stakeholders (i.e. pre-service teachers, in-service teachers, and teacher educators) with regard to the appropriateness of the BA courses they were attending. According to the results, the majority of the participants hold similar attitudes toward the courses. However, there were significant differences among these groups with regard to a few courses. The results concerning these courses are depicted in detail in Tables 1, 2 .

Table 1

ANOVA results regarding each course in teacher education program in TEFL

\begin{tabular}{|c|c|c|c|c|c|c|c|}
\hline \multirow{3}{*}{ Course Name } & \multirow{3}{*}{ Result } & \multicolumn{6}{|c|}{ Group Mean / SD } \\
\hline & & \multicolumn{2}{|c|}{$\mathrm{PT}^{*}$} & \multicolumn{2}{|c|}{$\mathrm{IT}^{*}$} & \multicolumn{2}{|c|}{ TE" } \\
\hline & & Mean & SD & Mean & SD & Mean & $\mathrm{SD}$ \\
\hline Language Study Skills & $\begin{array}{l}F(2,137)=6.7 \\
p=.02\end{array}$ & 4.3 & .21 & 3.50 & .57 & 7.23 & .66 \\
\hline Phonetics \& Phonology & $\begin{array}{l}F(2,137)=5.04 \\
p=.02\end{array}$ & 8.3 & .53 & 5.50 & .63 & 8.91 & .92 \\
\hline Media English & $\begin{array}{l}\mathrm{F}(2,137)=5.68 \\
p=.02\end{array}$ & 8.2 & .58 & 5.10 & .83 & 8.53 & .72 \\
\hline $\begin{array}{l}\text { Principles of High School Lesson } \\
\text { Planning (Held in Persian) }\end{array}$ & $\begin{array}{l}\mathrm{F}(2,137)=5.62 \\
p=.02\end{array}$ & 10. & 0 & 6.03 & .33 & 10.00 & 0 \\
\hline $\begin{array}{l}\text { Materials Development (Held } \\
\text { in Persian) }\end{array}$ & $\begin{array}{l}\mathrm{F}(2,137)=5.43 \\
p=.04\end{array}$ & 9.3 & .79 & 6.37 & .97 & 10.00 & 0 \\
\hline Research Methodology & $\begin{array}{l}\mathrm{F}(2,137)=6.3 \\
p=.03\end{array}$ & 8.4 & .91 & 4.61 & 1.06 & 9.31 & 1.02 \\
\hline Materials Evaluation & $\begin{array}{l}\mathrm{F}(2,137)=6.21 \\
p=.03\end{array}$ & 8.9 & .48 & 5.34 & .23 & 9.56 & .58 \\
\hline
\end{tabular}

Note: PT: Pre-service Teachers; IT: In-service Teachers; TE: Teacher Educators 
Table 2

Post-hoc comparisons among three groups of stakeholders

\begin{tabular}{|c|c|}
\hline Name of the course & Post-hoc results \\
\hline Language Study Skills & $\begin{array}{l}\text { The mean score for PT* group was significantly different } \\
\text { from the TE* group; the mean score for IT* group was } \\
\text { significantly different from TE group. There is no statis- } \\
\text { tically significant difference between PT and IT groups. }\end{array}$ \\
\hline Phonetics and Phonology & $\begin{array}{l}\text { The mean score for PT group was significantly different } \\
\text { from the TE group; the mean score for IT group was signi- } \\
\text { ficantly different from TE group. There was no statistically } \\
\text { significant difference between PT and IT groups. }\end{array}$ \\
\hline Media English & $\begin{array}{l}\text { The mean score for IT group was significantly different } \\
\text { from both TE and PT group. There was no statistically } \\
\text { significant difference between PT and TE groups. }\end{array}$ \\
\hline $\begin{array}{l}\text { Principles of High School Lesson } \\
\text { Planning (Held in Persian) }\end{array}$ & $\begin{array}{l}\text { The mean score for IT group was significantly different } \\
\text { from both TE and PT groups. There was no statistically } \\
\text { significant difference between PT and TE groups. }\end{array}$ \\
\hline $\begin{array}{l}\text { Oral Reproduction of Short } \\
\text { Stories }\end{array}$ & $\begin{array}{l}\text { The mean score for PT group was significantly different } \\
\text { from the TE group; the mean score for IT group was signi- } \\
\text { ficantly different from TE group. There was no statistically } \\
\text { significant difference between PT and IT groups. }\end{array}$ \\
\hline $\begin{array}{l}\text { Materials Development (Held } \\
\text { in Persian) }\end{array}$ & $\begin{array}{l}\text { The mean score for IT group was significantly different } \\
\text { from both TE and PT groups. There was no statistically } \\
\text { significant difference between PT and TE groups. }\end{array}$ \\
\hline Research Methodology & $\begin{array}{l}\text { The mean score for PT group was significantly different } \\
\text { from the TE group; the mean score for IT group was signi- } \\
\text { ficantly different from TE group. There was no statistically } \\
\text { significant difference between PT and IT groups. }\end{array}$ \\
\hline Materials Evaluation & $\begin{array}{l}\text { The mean score for IT group was significantly different } \\
\text { from both TE and PT groups. There was no statistically } \\
\text { significant difference between PT and TE groups. }\end{array}$ \\
\hline
\end{tabular}

Note: PT: Pre-service Teachers; TE: Teacher Educators; IT: In-service Teachers

As Tables 1 and 2 indicate, there were significant differences among the three groups of participants with regard to Language Study Skills, Phonetics and Phonology, Media English, Principles of High School Lesson Planning, Oral Reproduction of Short Stories, Material Development, Research Methodology, and Material Evaluation courses in this teacher education program. In the rest of the courses, no significant difference was found among the participants.

The results can be also approached from another perspective, namely, the participants' opinions with regard to maintaining the courses in or excluding them from the program. In this respect, the mean scores for each course were divided into three categories (1-4, 4.1-7, and 7.1-10). The first category (1-4) indicated the participants' agreement on excluding the courses. The second category (4.1-7) indicated the participants' uncertainty about maintaining or excluding the courses, and the last category (7.1-10) indicated the participants' agreement on maintaining the courses. Table 3 provides the findings on this aspect of this study. 
Table 3

Stakeholders' attitudes on maintaining or excluding courses in teacher education program in TEFL

\begin{tabular}{llll}
\hline \multicolumn{1}{c}{ Pre-service teachers } & \multicolumn{1}{c}{ In-service teachers } & \multicolumn{1}{c}{ Teacher educators } \\
\hline $1.0-4.0$ & Item & Items & Items \\
& $23,15,18,43,45,47$ & $3,23,43,47,15,18,45$ & $23,15,18,45,47$ \\
\hline $4.1-7.0$ & Items & Items & Items \\
& $3,22,29,31,38$ & $35,36,38,40$ & $22,31,38,43$ \\
& & Items & \\
\hline $7.1-10.0$ & Items & Items \\
& $1,2,4,5,6,7,8,9,10$, & $1,2,4,5,6,7,8,9,10$, & $1,2,3,4,5,6,7,8,9$, \\
& $11,12,13,14,16,17$, & $11,12,13,16,17,19$, & $10,11,12,13,14,16$, \\
& $19,20,21,24,25,26$, & $20,21,25,26,27,30$, & $17,19,20,21,24,25$, \\
& $27,28,30,32,33,34$, & $32,33,34,37,39,41$, & $26,27,28,29,30,32$, \\
& $35,36,37,39,40,41$, & $42,44,46$ & $33,34,35,36,37,39$, \\
& $42,44,46$ & & $40,41,42,44,46$ \\
\hline
\end{tabular}

The results suggested that the participants did not have significantly different attitudes towards the relevance of the majority ( $83 \%)$ of the courses presented in the BA program in TEFL at FUs to their use in the teaching context. In other words, the participants had significantly different attitudes towards only $17 \%$ of the courses. The insignificant results among the participants in $83 \%$ of the courses imply a consensus among them with regard to these courses. The consensus includes both negative and positive attitudes among the participants, which will be discussed later. The significant results, however, is much more worthy of noting and, hence, require an in-depth discussion.

\section{Discussion}

The first significant result was related to the course entitled "Study skills" (item 3). This course instructed the students on the basic skills in order to have an efficient study. For instance, it provided the learners with lessons focusing on how to use the dictionary, what the appropriate study place is, or how to take notes while studying. Both pre-service and in-service teachers ranked this course as redundant, while the teacher educators held more favourable ideas on its inclusion in the program. This may be due to the possibility that the student teachers felt competent enough in those skills and therefore found it useless. The in-service teachers' low ranks in this regard could be attributable to the course's irrelevancy to their authentic teaching practices. The teacher educators, however, might have given a higher score in comparison to the other groups since, as stated in a number of comments, they felt the necessity for the BA students to be familiarized well enough with the fundamental study skills.

The second significant result was found in "Phonology" course (item 14). In this course, the learners were provided with rudimentary information about the phonology and phonetics of the language. The significant result was due to the difference between the in-service teachers and the other two groups. That is, the pre-service and teacher educators both gave a lower rate to this course in comparison to the in-service teachers. The reason the trainers were more in favour of this course may be that the teacher educators see the teachers' pronunciation and accent as models for students whom they teach. This is, indeed, what a number of teacher educators stated in their comments. A 
few of the teacher educators also found this course beneficial to student teachers in their future teaching recruitment in private language schools. In Iran, as well as in many other countries, a native-like pronunciation is considered a plus if not a must for teachers. As Medgyes (2001) states, native or native-like teachers benefit from more job opportunities compared with the ones whose pronunciation and accent is not native-like. Therefore, as pronunciation is an inseparable and prominent component of a native-like proficiency, the teacher educators might have rated this course as highly significant. The pre-service teachers stated their willingness to work in the private sector after graduation along their teaching in public schools. The comments by the student teachers were similar in content to those provided by teacher educators, that is, there is a relationship between native-like pronunciation and job opportunities in private language schools. In addition, a good number of pre-service teachers found native-like pronunciation as a prestige-enhancing aspect. The reason for in-service teachers' negative attitudes toward this course can be attributed to their recruitments in public schools. In these schools, teachers are not evaluated based on their pronunciation. In fact, the student teachers at FUs are guaranteed a teaching job at public schools regardless of their pronunciation. This is reflected in the comments the in-service teachers have provided for this course.

The third significant result was observed in the "Media English" course (item 24). In this course, the students are provided with authentic news pieces in both written and oral modes and they are expected to comprehend the discourse of the news. The preservice teachers and teacher educators gave significantly higher scores as compared with the in-service teachers for the aforementioned course. As declared by in-service teachers and teacher educators, Media English course has a great contribution in improving the proficiency of the teachers. Moreover, a number of pre-service teachers commented that understanding media English makes them stand out among the majority of English teachers in Iran. The main reason may be the fact that a majority of Iranian teachers are not proficient enough in media English comprehension. In contrast, the in-service teachers found this course ineffective in the teaching context. In their idea, the course has the least relevance to their real professions in schools. Instead, they suggested that Media English could be replaced by courses such as classroom management, teaching language components, and real class observation and report, particularly, in public schools. For this purpose, it was suggested that it may be more helpful to incorporate some language teaching courses in pre-service programs. They also proposed that more courses related to micro-teaching be included in the program so that the pre-service teachers would be readier for the real teaching practice in the classroom. What is implicit in those comments is that this course is not aligned with the realities of the teaching context. This finding is in line with Seferoglu's (2006) and Adamson's (2012) claim that the pre-service teacher education programs, in some cases, do not simulate the teaching setting. And if this occurs, teachers will not be sufficiently prepared for the real teaching practice (Seferoglu, 2006). Similarly, Freeman and Johnson (1998) stressed the importance of making teachers familiar with the realities of the social context of learning, in this case public school classes, since it is an essential feature of learning and teaching process.

Another significant result was observed in "Principles of High School Lesson Plans" course (item 28). In this course, students get familiar with the most essential principles in lesson planning for high school. The pre-service and teacher educators both rated this course as the most relevant course, while the in-service teachers considered the course as the least appropriate one. In-service teachers' attitudes toward this course is 
not surprising since, in most cases, Iranian teachers are provided with a pre-packaged lesson plan suggested by The Ministry of Education at the beginning of the school year and are required to follow it step by step without making any changes in it. The interesting point in this respect was the comments provided by some in-service teachers. These teachers mostly stated that including this course in the BA program was very useful for teachers. However, the educational system in Iran, in a way, prevents the teachers from developing their own lesson plans. These teachers also stated that, in most cases, they were not in favour of the lesson plans provided by The Ministry of Education as they found many defects in these lesson plans which resulted in a poor quality of teaching. Based on these reasons, the in-service teachers might have given a low score to this course. Among the teachers, some argued that they would have given a high score to this course if they could indeed make use of it in their teaching context (i.e., high schools).

The pre-service teachers, however, did not seem to have a true perception of the realities of the teaching context (i.e., high school), in Iran. This was observed in the comments provided by a few of the participants in this group. There were some preservice teachers whose comments opposed the ones provided by the in-service teachers. For instance, one of the participants wrote "I'm happy that I've studied this course. I think I can develop great lesson plans for my classes in school". There was another participant who held a similar attitude "This course was one of the best courses we passed in BA. Being familiar with the principles of lesson planning, I can be different from the teachers in school, of course in a good way. Great classes need great lesson plans. I can give this course even a rating above the maximum". Based on such comments, it seems that these pre-service teachers are not adequately aware that they will have few opportunities to develop their own lesson plans or even revise the one provided by The Ministry of Education. Having found this course very useful, which is in line with the opinions of in-service teachers, and is accompanied with an unawareness of the realities of the teaching context (excluding the in-service teachers), the pre-service teachers might have given a high score to this course.

The very high score given by teacher educators to this course indicates that they believed in the usefulness and necessity of this course to teachers. It goes without saying that the very basic requirement of running any class is a well-structured lesson plan which is developed based on the needs and characteristics of that class. As a result, the teacher educators felt the need to pay extra attention to the aforementioned course and not overlook its requirements. As teacher educators, it would be ignorant of them to neglect this fact and undervalue the importance of this course. The comments provided by two teacher educators in this regard are worthy of noting. The two teacher educators stated that it is a pity that teachers in schools are not allowed to develop their own lesson plans. These comments support the ideas of in-service teachers in that this course has little to do in the real context, although it is of high importance in any classroom context.

The same findings and discussion also hold true for "Material Development" course (item 35). Similar comments were also found for this course indicating that in-service teachers have true understanding of the realities of the teaching context, while their counterparts (pre-service teachers) do not always have these true perceptions. This could be due to their lack of involvement in the real teaching practice in the target teaching context. 
The next significant result was found in the course entitled "Oral Reproduction of Short Stories" (item 29). In this course, the students are required to retell stories orally in class. The pre- and in-service teachers both gave a significantly lower priority to this course as compared to the teacher educators. It is possible that in-service teachers had not found this course useful in their teaching context, since it did not add anything to their teaching strengths. The pre-service teachers might have had the same opinion, since they have experienced seven years of studying English at school and have not observed their teachers telling stories in the class. In a comment, one of the pre-service teachers argued that "I have never seen any of my English teachers tell stories to us in any classes. And I don't think I would ever need to tell any English stories in my classes. I don't understand why we need to pass this course at university." The teacher educators, on the other hand, believed that this course could contribute to students' improvements in general English proficiency and fluency.

The next significant result was related to the "Research Methodology" course. The in-service teachers gave a significantly lower score to this course in comparison to preservice teachers and teacher educators. The reason may be ascribable to the fact that research has no place in public schools in Iran. As in-service teachers put it, conducting research could be constructive within the class as it could alleviate some of the common problems in the teaching context. However, as the teachers found the research results inapplicable in the classroom setting, they mostly lacked the necessary motivation to carry out research. A few of the in-service teachers also stated that they wished there had been a committee in The Ministry of Education to which they could report the research findings so that the Ministry would possibly consider those results in their policies. As it was discussed earlier, pre-service teachers sometimes may harbour false perceptions of the teaching context. Teacher educators, on the other hand, viewed research, particularly the action research, as an indispensable characteristic of an efficient teacher.

"Material Evaluation" course can also be discussed from the same perspective. Such findings, in general, indicated that in-service teachers' opinions should be taken into account when designing and preparing courses for pre-service teachers at FUs. The main reason for this may be the fact that in-service teachers are directly involved in the teaching practice in the target context and, therefore, have true perceptions of the realities of these contexts.

Moreover, the data can be approached from a different perspective. The comments of the participants can be employed as a help in the maintenance or omission of the program. This fact underscores the importance of the insignificant findings. Accordingly, the courses can be categorized into three major groups (group 1: 1-4, group 2: 4.1-7, group 3: 7.1-10, see Table 3).

The findings indicated that all the courses related to English literature lay in the first group. This means that the participants have opted for the omission of these courses from the program. This might be caused by the fact that literary courses have no use in the teaching practice of the teachers in the real context. This finding is in line with AlGaeed (1983) who reported that the pre-service and in-service teachers considered the literary courses as irrelevant to their preparation.

The other course for which similar results were obtained was the "Typing" course. This finding is not surprising as typing has little place in teaching language in Iranian schools. The comments provided by some participants give support to this interpretation. The participants' opinions about the omission of typing and literary courses indicate 
that these courses do not foster sustainable ability as far the job at hand is concerned. This implies that presenting these courses for pre-service teachers is of no use for them in their future career as a teacher. It would be a better idea to replace these courses by ones that are more related to teaching, which are apparently more sustainable.

The findings related to the translation courses indicated that these courses fell within the second group in the above-mentioned categorization. The translation courses might not have immediate use in the teaching context. However, this course may be useful in translating texts from Persian to English or vice versa. Indeed, a number of participants expressed that this course helped them in their translation jobs.

All the other courses fell under the third category, which means that the participants were satisfied with their existence in BA program in TEFL. These courses were either related to teaching, such as Teaching Methodology course, general English courses, such as Reading and Grammar, or Linguistics courses. This finding was indeed anticipated as it is generally believed these are the fundamental courses for a teacher preparation program.

Taking the ideas of in-service teachers into account can result in a more sustainable teacher education program since they are already in the job and well familiar with the realities and challenges of the classroom and educational issues. Besides, gathering the data from the other two key stakeholders provides us with a more robust account of the educational system and its demands and, thus, leads to a more sustainable reform in the educational system.

\section{Implications, Conclusions and Debate of Future Research}

In this study, we aimed at exploring the Iranian pre-service and in-service teachers' as well as teacher educators' attitudes towards the teacher preparation programs at the BA level in TEFL at FUs. In addition, this research examined, from the participants' perspective, whether the courses should be maintained, modified, or replaced by other courses.

In conclusion, this study found that the three groups of participants were unanimous in their evaluations of the majority of the courses, while their evaluative perceptions significantly varied for a small fraction of the courses in the program. The findings also revealed that the three groups harboured strikingly identical conceptions in maintaining and excluding some courses. The participants had a positive attitude towards the maintenance of most of the courses addressing teaching methodology and practice. Moreover, they were unanimous in omitting and replacing the courses related to translation and English literature. They also believed that there is a need for inclusion of practical courses like practice- and micro-teachings as well as real classroom observations. The in-service teachers had a negative attitude toward the courses that did not have practical nature in their classrooms, even the ones that are related to teaching practice, methodology, and planning but are of no immediate use in the classroom. The pre-service teachers and teacher educators found only the courses that are not related to teaching, that is, literary courses and typing, as irrelevant and suggested that these courses be amended or even be replaced by some other courses.

The results of the study provide some pedagogical implications that can be of help for EFL teacher educators, syllabus designer, and policy makers at universities. The findings of this study can contribute to re-evaluation of the courses presented in English 
Language Teacher Education Programs so that the courses that are not related to the teaching, like courses related to literature and translation, would be excluded and amended. Furthermore, based on the findings, it is suggested that the courses which are related to teaching but not aligned with the realities of the teaching context can be improved in a way that they match the goals of the program and the teaching context in real classrooms. The in-service teachers' opinions, as the ones who are in direct contact with the classroom context and are well familiar with the realities and challenges of EFL classes at schools as well as the educational issues, should also be considered in setting educational policies and selecting the courses to be taught at universities. Through catering to the program evaluations of these key stakeholders, one could craft a more tailored teacher education program in similar contexts. Besides, exploring the program evaluation views of the other two key stakeholders provides us with a more robust mosaic picture of how this program is viewed in Iran.

\section{References}

Adamson, B. (2012). International comparative studies in teaching and teacher education. Teaching and Teacher Education, 28, 641-648.

Al Barwani, T., Al-Mekhlafi, A., \& Nagaratnam, R. P. (2013). Service-Learning Might be the Key: Learning From the Challenges and Implementation Strategies in EFL Teacher Education in Oman. International Journal of Instruction, 6(2), 109-128.

Al-Gaeed, I. H. (1983). An evaluative study of the English as a foreign language teacher preparation programs of Saudi Arabia as perceived by program students and graduate (Unpublished doctoral dissertation). Indiana University: Indiana, USA.

Barone, T., Berliner, D. C., Blanchard, J., Casanova, U., \& McGowan, T. (1996). A future for teacher education. In J. Sikula, T. Buttery, \& E. Guyton (Eds.), Handbook of research on teacher education (2 ${ }^{\text {nd }}$ ed., pp. 1108-1149). New York: Macmillan.

Beretta, A., \& Davies, A. (1985). Evaluation of the Bangalore Project. ELT Journal, 39, $121-127$.

Besong, F., \& Holland, C. (2015). The dispositions, abilities and behaviors (DAB) framework for profiling learners' sustainability competencies in higher education. Journal of Teacher Education for Sustainability, 17(1), 5-22.

Cosgun-Ogeyik, M. (2009). Evaluation of English Language Teaching Education Curriculum by Student Teachers. Insan ve Toplum [Human and Society]. 9(1), 42-57.

Day, R. R. (1991). Models and the knowledge base of second language teacher education. East Lansing, MI: National centre for Research on Teacher learning.

Erozan, F. (2005). Evaluating the language improvement courses in the undergraduate ELT curriculum at Eastern Mediterranean University: A case study (Unpublished doctoral thesis). Middle East Technical University, Ankara, Turkey.

Freeman, D., \& Johnson, K. E. (1998). Reconceptualising the knowledge-base of language teacher education. TESOL Quarterly, 32, 397-417.

Gholami, J., Sarkhosh, M., \& Abdi, H. (2016). An exploration of teaching practices of private, public, and public-private EFL teachers in Iran. Journal of Teacher Education for Sustainability, 18(1), 16-33.

Lucas, T., Villegas, A. M., \& Freedson-Gonzalez, M. (2008). Linguistically responsive teacher education: Preparing classroom teachers to teach English language learners. Journal of Teacher Education, 59, 361-373. 
Lynch, B. K. (2003). Language assessment and program evaluation. Edinburgh: Edinburgh University Press.

Medgyes, P. (2001). When the teacher is a non-native speaker. In M. Celce-Murcia (Ed.), Teaching English as a second or foreign language (pp. 429-442). Boston: Heinle \& Heinle.

Peacock, M. (2009). The evaluation of foreign-language-teacher education programs. Language Teaching Research, 13, 259-78.

Rea-Dickins, P., \& Germaine, K. P. (1998). The price of everything and the value of nothing: trends in language program evaluation. In P. Rea-Dickins, \& K. P. Germaine (Eds.), Managing evaluation and innovation in language teaching: building bridges (pp. 3-19). London: Longman.

Redman, E. (2013). Opportunities and challenges for integrating sustainability education into k-12 schools: Case study phoenix, AZ. Journal of Teacher Education for Sustainability, 15(2), 5-24.

Richards, J. C., \& Schmidt, R. (1985). Dictionary of language teaching and applied linguistics. London: Pearson Education.

Sandlin, R. A., Young, B. L., \& Karge, B. D. (1992). Regularly and alternatively credentialed beginning teachers: Comparison and contrast of their development. Action in Teacher Education, 14, 16-23.

Seferoglu, G. (2006). Teacher candidates' reflections on some components of a preservice English teacher education program in Turkey. Journal of Education for Teaching, 32, 369-378.

Seyoum, Y. (2016). Analysis of faculty members attitude towards academic development endeavors in some selected ethiopian universities. International Journal of Instruction, 9(1), 41-64.

Sullivan, J. H. (2006). The importance of program evaluation in collegiate foreign language programs. The Modern Language Journal, 90, 590-593.

Weir, C., \& Roberts, J. (1994). Evaluation in ELT. Oxford: Blackwell.

White, R. (1998). What is quality in English language teacher education? English Language Teaching Journal, 52, 133-39.

Widdowson, H. G. (1990). Aspects of language teaching. Oxford: Oxford University Press.

Yang, W. (2009). Evaluation of teacher induction practices in a US university English language program: Towards useful evaluation. Language Teaching Research, 13, 77-98.

Correspondence concerning this paper should be addressed to Javad Gholami, PhD, Department of English, Faculty of Humanities, Urmia University 165, Urmia, IRAN. Email: j.gholami@urmia.ac.ir 
Appendix

\section{Teacher Education Program Evaluation Questionnaire (Adapted from Peacok, 2009)}

Thank you very much for taking part in this survey. Your participation is voluntary, and confidential treatment of your information is guaranteed by the researchers. The results will be discussed and published in whole, and if presented individually, it would be done so without revealing any personal details. Participation in this study causes no harm or danger. The results are going to be published and, thus, used by those who are interested.

This questionnaire is designed to evaluate the courses given to the university students at Farhangian teacher education programs in Iran. The purpose is to see if these courses should be maintained, improved or excluded or need replacements. In the first column, you evaluate the course by Fridman Rank Order scale, giving 1-10 relevance scale, that is, if you think the most relevance of the given course, give 10 and the least one receives 1 , followed by four other columns. In the second column, you can agree on maintaining the course if you think that the individual course meets the student teachers' needs while the third column focuses on the improvement. It happens when the participants believe that the course is necessary for student teachers to cover but either in content or the way of performing or even the authenticity of the course needs some changes and also the part needs special changes, in other words, what aspects regarding that course require improvement. The same judgement occurs on the forth column, that is to say, the participants decide on the exclusion of the course and finally tentative replacement which seem optional.

\begin{tabular}{|c|c|c|c|c|c|c|}
\hline \multicolumn{2}{|l|}{ Course Name } & \multirow{2}{*}{$\begin{array}{c}\text { Scale of } \\
\text { Relevance } \\
1-10\end{array}$} & \multirow[b]{2}{*}{ Maintain } & \multirow{2}{*}{$\begin{array}{l}\text { Improve } \\
\text { (specify it) }\end{array}$} & \multirow{2}{*}{ Exclude } & \multirow{2}{*}{$\begin{array}{c}\text { Tentative } \\
\text { Replace- } \\
\text { ment }\end{array}$} \\
\hline & $\begin{array}{l}\text { Credit } \\
\text { Num. }\end{array}$ & & & & & \\
\hline 1 & 2 & 3 & 4 & 5 & 6 & 7 \\
\hline \multicolumn{7}{|l|}{ Semester one } \\
\hline 1. Reading Comprehension (1)* & 4 & & & & & \\
\hline 2. Grammar $(1)^{* *}$ & 4 & & & & & \\
\hline 3. Language Study Skill** & 2 & & & & & \\
\hline \multicolumn{7}{|l|}{ Semester two } \\
\hline 4. Reading Comprehension (2)*** & 4 & & & & & \\
\hline 5. Grammar $(2) * *$ & 4 & & & & & \\
\hline 6. Psychology (held in Persian)** & 2 & & & & & \\
\hline \multicolumn{7}{|l|}{ Semester 3} \\
\hline 7. Conversation $(1) * *$ & 4 & & & & & \\
\hline 8. Language Grammar (3)*** & 2 & & & & & \\
\hline 9. Writing (1) (Basic Writing)** & 2 & & & & & \\
\hline 10. Reading Comprehension (3)** & $* 4$ & & & & & \\
\hline $\begin{array}{l}\text { 11. Language Teaching Method- } \\
\text { ology (held in Persian) } * * *\end{array}$ & 4 & & & & & \\
\hline $\begin{array}{l}\text { 12. Childhood and Young } \\
\text { Adult Psychology } * * *\end{array}$ & 2 & & & & & \\
\hline \multicolumn{7}{|l|}{ Semester four } \\
\hline 13. Conversation $(2)^{* *}$ & 4 & & & & & \\
\hline
\end{tabular}

Sequel to Table see on the next page. 
Sequel to Table.

\begin{tabular}{|c|c|c|c|c|c|c|}
\hline 1 & 2 & 3 & 4 & 5 & 6 & 7 \\
\hline 14. Phonetics \& phonology** & 2 & & & & & \\
\hline 15. Simple Prose $* *$ & 2 & & & & & \\
\hline 16. Linguistics $(1)^{* * *}$ & 2 & & & & & \\
\hline 17. Writing $(1)^{* *}$ & 2 & & & & & \\
\hline 18. Simple Poetry $* *$ & 2 & & & & & \\
\hline $\begin{array}{l}\text { 19. Advanced Reading Compre- } \\
\text { hension }(4)^{* *}\end{array}$ & 2 & & & & & \\
\hline $\begin{array}{l}\text { 20. Mentoring \& Counselling } \\
\text { (held in Persian) } * * *\end{array}$ & 2 & & & & & \\
\hline \multicolumn{7}{|l|}{ Semester Five } \\
\hline 21. Linguistics $(2)^{* * *}$ & 2 & & & & & \\
\hline 22. Translation Principles*** & 2 & & & & & \\
\hline 23. Typing** & 2 & & & & & \\
\hline 24. Media English*** & 2 & & & & & \\
\hline 25. Topic Based Conversation*** & 2 & & & & & \\
\hline 26. Conversation $(3) * *$ & 2 & & & & & \\
\hline 27. Writing $(2) * *$ & 2 & & & & & \\
\hline $\begin{array}{l}\text { 28. Principles of High School Les- } \\
\text { son Planning (held in Persian)*** }\end{array}$ & 2 & & & & & \\
\hline
\end{tabular}

Semester Six

29. Oral Reproduction of Short Stories**

\begin{tabular}{|c|c|}
\hline 30. Conversation $(4) * *$ & 2 \\
\hline 31. Translation $(1)^{* *}$ & 2 \\
\hline $\begin{array}{l}\text { 32. Language Idioms and } \\
\text { Expressions** }\end{array}$ & 2 \\
\hline $\begin{array}{l}\text { 33. Teaching Methodology } \\
\text { (theories)* }\end{array}$ & 4 \\
\hline 34. Contrastive Analysis* & 2 \\
\hline $\begin{array}{l}\text { 35. Material Development } \\
\text { (held in Persian)**** }\end{array}$ & 2 \\
\hline 36. Research Methodology* & 2 \\
\hline \multicolumn{2}{|l|}{ Semester Seven } \\
\hline $\begin{array}{l}\text { 37. Educational Management } \\
\text { (held in Persian***) }\end{array}$ & 2 \\
\hline 38. Translation $(2)^{*}$ & 2 \\
\hline 39. Teaching Language Skills* & 2 \\
\hline 40. Materials Evaluation* & 2 \\
\hline 41. Practical Teaching $(1)^{*}$ & 2 \\
\hline 42. Error Analysis* & 2 \\
\hline 43. English Literature $(1)^{* * *}$ & 2 \\
\hline \multicolumn{2}{|l|}{ Semester Eight } \\
\hline 44. Practical Teaching $(2)^{*}$ & 2 \\
\hline $\begin{array}{l}\text { 45. English Language Literature } \\
(2)^{*}\end{array}$ & 4 \\
\hline
\end{tabular}


Sequel to Table.

\begin{tabular}{lllllll}
\hline \multicolumn{1}{c}{1} & 2 & 3 & 4 & 5 & 6 & 7 \\
\hline 46. Testing* & 2 & & & & & \\
\hline 47. English Literature $(2)^{* *}$ & 2 & & & & & \\
\hline
\end{tabular}

Notes: ${ }^{*}=$ Specific Course, ${ }^{* *}=$ Main Course, ${ }^{* *}=$ Educational Psychology Courses (taken by all fields at Farhangian teacher education universities in Iran)

Courses Needing Improvement

Course Number Aspect(s) to modify

Suggested Additional ideas for Inclusion

1.

2.

Thanks for Your Participation 